\title{
Clinical results after surgical treatment in young male patients with low grade isthmic spondylolisthesis
}

\section{Düşük dereceli ïstmik spondilolistezis nedeni ile opere edilen 20-29 yaş arası genç erkek hastalarda cerrahi sonrası klinik sonuçlarımız}

\author{
Ahmet Eroğlu*,Cem Atabey**
}

*Haydarpaşa Sultan Abdülhamid Eğitim Araştırma Hastanesi,Beyin Cerrahi Servisi, Istanbul

**Yıldırım Beyazit Eğitim Araştırma Hastanesi,Beyin Cerrahi Servisi,Ankara

\begin{abstract}
Purpose:The aim of this study is to evaluate the long term results of surgical treatment in young patients with low grade isthmic spondylolisthesis (IS).

Materials and methods:Postoperative clinical results of 42 patients ageing between 20-29 were retrospectively analized in this study. Oswestry Disability Index (ODI) and Visual Analog Scales (VAS) scores were used to compare patients' preoperative and postoperative pain levels.

Results: All patients were male and the mean age of patients was 23.4 (between 20-29). Mean duration of symphtoms was 1.8 years (between 1-4 years). All patients had physical therapy before surgery and 24 patients (\%57.1) used lumbosacral brace. Isthmic spndylolisthesis was present in L5-S1 level in 78.5\% $(n=33)$ and in L4-5 level in $21.4 \%(n=9)$ of the patients. Mean preoperative ODI and VAS scores were 76.68 (between 43-100) and 5.98 (between 3-10), respectively $(p<0.05)$. Mean postoperative ODI and VAS scores were 26.65 (between $0-66)$ and 2.49 (between $0-5)$, respectively $(p<0.05)$.

Conclusion:Posterolateral in stu fusion and transpedicular instrumentation in young well-selected patients with low grade IS reduce pain, improve function and result good clinical outcome. Prospective and multicenter studies with 10-20 years follow-up are needed for further data.
\end{abstract}

Pam Med J 2017;10(3):264-269

Keywords:Isthmic spondylolisthesis, Young, Posterior stabilisation,Transpedicular fixation.

Özet

Amaç: Bu çalışmanın amacı,istmik spondilolistezisli (IS) genç hastalarda cerrahinin uzun dönem sonuçlarını değerlendirmektir.

Gereç ve yöntem: Çalışmamızda,20-29 yaş arası cerrahi yapıımış 42 hastanın klinik sonuçlarının restrospektif analiz edilmiştir.Hastaların ağrıların seviyeleri preoperatif ve postoperatif dönemlerde Oswestry Disability Index (ODI) ve Visual Analog Scales (VAS) skorları ile değerlendirildi.

Bulgular: Tüm hastalar erkekti ve ortalama yaş 23.4 yıldı (20-29 yıl).Semptomların ortalama süresi 1.8 yıldı (1-4 yıl arası). Tüm hastalar ameliyat öncesi dönemde fizyoterapi görmüştü ve sadece 24 hasta çelik balenli korse kullanmıştı. Hastaların \%78.5 ( $n=33$ )'inde L5-S1,\%21.4 ( $n=9$ )'ünde L4-5 seviyesinde istmik spondilolistezis mevcuttu.Preoperatif ODI ve VAS skorları ortalama 76.68 (43-100 arası) ve 5.98 idi $(3-10$ arası) $(p<0.05)$. Postoperatif ODI ve VAS skorları ortalama 26.65 (0-66 arası) ve $2.49(0-5$ arası)'du $(p<0.05)$.

Sonuç: 20-29 yaş arası İ'li genç hastalarda radyolojik ve klinik bulguların birlikte değerlendirilip uygun hasta seçimi yapıldığında posterolateral in situ füzyon ile transpediküler enstrümantasyon ağrıları azaltır, klinik düzelme sağlayarak anlamlı düzeyde fonksiyonel iyileşme sağlar. Hastaların yaş grubunun genç olmasından dolayı çok merkezli 10-20 yıl takip süreli prospektif çalışmaların faydalı olacağını düşünmekteyiz.

Pam Tıp Derg 2017;10(3):264-269

Anahtar sözcükler:İstmik Spondilolistezis, Genç, Posterior Stabilizasyon, Transpediküler Fiksasyon.

Ahmet Eroğlu

Yazışma Adresi:Haydarpaşa Sultan Abdülhamid Eğitim Araştırma Hastanesi, Beyin Cerrahi Servisi, İstanbul e-mail:drahmeteroglu@gmail.com 


\section{Introduction}

Isthmic spondylolisthesis, estimated to be seen in $4-8 \%$ of general population, is the most common type of spondylolisthesis [1,3]. Changes or defects occur in pars interarticularis in lumbar vertebrae may lead to isthmic spondylolisthesis $[4,6]$. Genetic, hormonal and mechanical factors may play role in the developement process. Clinical findings may be due to spinal deformities or compromise of the neurological structures $[2,7]$. Surgical intervention may be needed if conservative managements are failed to control pain or neurological symptoms worsen $[4,7]$. Surgical options include neural decompression, bone fusion, and stabilisation-fusion with instrumentation $[2,8]$. The aim of this study is to evaluate the clinical outcomes after surgery in young patients with isthmic spondylolisthesis by using Oswestry Disability Index (ODI) and Visual Analog Scales (VAS).

\section{Material-Method}

Clinical outcomes of 42 patients which were operated with the diagnose of grade 1 L4-5 or L5-S1 isthmic spondylolisthesis between December 2012-June 2015 were retrospectively analized in our study. All patients were aged between 20-29 years and suffered lumbar pain, decreased lumbar range of motion and unable stand up for a long time. Conservative treatment was administered for all patients before surgery (mean time: 1.8 years, between 1-4 years). Patients with former spinal surgery history, lumbar disc hernia or traumatic spondylolisthesis were excluded. Conventional lumbosacral x-ray, lumbar computerized tomography (CT) and lumbar magnetic resonance imaging (MRI) were used for patient evaluation. All patients were gone under posterolateral in stu fusion and transpedicular short segment instrumentation procedure (Figure 1). Mean follow-up time was 11.6 months (between 7,5-16 months). Preoperative and postoperative ODI and VAS scores were evaluated in the end of follow-up period. Statistical analyses were conducted with SPSS version 15.0 statistical software. Kolmogorov-Smirnov test was used to assess normal distribution. Differences in continuous variables following normal distribution were examined using $t$ test. $\mathrm{P}<0.05$ was considered significant.

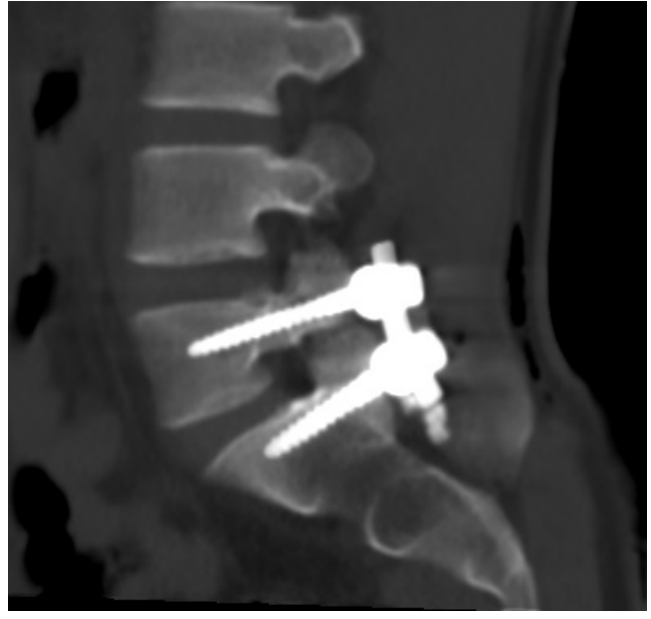

Figure 1.All patients were gone under posterolateral in stu fusion and transpedicular Fertheggment instrumentation procedure.

All patients were male and the mean age of patients was 23.4 (between 20-29). Most common occupations among the patients were coolies $(30.9 \%, n=13)$, farm worker $(23.9 \%$, $\mathrm{n}=10)$ and construction worker $(21.4 \%, \mathrm{n}=9)$. All patients had the complaints of lumbar pain, decreased lumbar range of motion and worsening in symptoms with prolonged standing. None of the patients had lower extremity pain related to radiculopathy. Mean duration of symptoms was 1.8 years (between 1-4 years). The most common affected level was L5-S1 $(n=33)$ (Table-1). Instability and instability related hipermobility in the affected level was observed intraoperatively. Mean operation time was 80 minutes (between 45 minutes-2.5 hours). Two of the 42 patients, who had no additional complaints, had undergone revision surgery due to detection of screw malposition in the control CT. None of the patients had the complications of infection and screw break. All but 3 patients' postoperative ODI and VAS scores improved significantly after 6 months following the surgery compared to preoperative scores. Mean preoperative ODI and VAS scores were 76.68 (between 43-100) and 5.98 (between 3-10), respectively $(p<0.05)$. Mean postoperative ODI and VAS scores were 26.65 (between 0-66) and 2.49 (between 0-5), respectively $(p<0.05) \quad($ Table- 2$)$. The three patients, whose complaints didn't resolve after the surgery, were still working in heavy duty. All patients were asked whether they accept the surgery or not if they had known the final result. Most of the patients (92.8\%) responsed positively.

\section{Discussion}


Table 1: General properties of the patients

\begin{tabular}{|c|c|c|c|c|c|c|c|}
\hline Patient & Age & Occupation & $\begin{array}{l}\text { Duration of } \\
\text { complaints } \\
\text { (year) }\end{array}$ & Level & Physiotheraphy & $\begin{array}{l}\text { Operation } \\
\text { time } \\
\text { (minute) }\end{array}$ & $\begin{array}{l}\text { follow-up } \\
\text { period (month) }\end{array}$ \\
\hline 1 & 22 & Carrier & 3 & L5-S1 & + & 90 & 9 \\
\hline 2 & 24 & Farm Worker & 2 & L4-L5 & + & 100 & 10 \\
\hline 3 & 21 & Driver & 2 & L5-S1 & + & 50 & 15 \\
\hline 4 & 25 & Construction Worker & 2 & L5-S1 & + & 100 & 12 \\
\hline 5 & 23 & Farm Worker & 3 & L5-S1 & + & 80 & 11 \\
\hline 6 & 22 & Carrier & 2 & L4-L5 & + & 90 & 12 \\
\hline 7 & 24 & Construction Worker & 3 & L5-S1 & + & 75 & 14 \\
\hline 8 & 25 & Farm Worker & 2 & L5-S1 & + & 90 & 12 \\
\hline 9 & 22 & Carrier & 3 & L4-L5 & + & 80 & 10 \\
\hline 10 & 22 & Farm Worker & 3 & L5-S1 & + & 60 & 12 \\
\hline 11 & 24 & Unemployed & 1 & L5-S1 & + & 120 & 12 \\
\hline 12 & 26 & Carrier & 4 & L5-S1 & + & 75 & 7.5 \\
\hline 13 & 24 & Barber & 1 & L5-S1 & + & 90 & 9 \\
\hline 14 & 22 & Farm Worker & 2 & L4-L5 & + & 100 & 12 \\
\hline 15 & 24 & Carrier & 2 & L5-S1 & + & 60 & 13 \\
\hline 16 & 21 & Carrier & 1 & L5-S1 & + & 75 & 16 \\
\hline 17 & 25 & Construction Worker & 2 & L5-S1 & + & 80 & 11 \\
\hline 18 & 22 & Farm Worker & 2 & L5-S1 & + & 150 & 12 \\
\hline 19 & 25 & Tourism sector & 1 & L5-S1 & + & 60 & 10 \\
\hline 20 & 22 & Unemployed & 2 & L5-S1 & + & 75 & 15 \\
\hline 21 & 25 & Carrier & 1 & L5-S1 & + & 90 & 10 \\
\hline 22 & 26 & Unemployed & 1 & L4-L5 & + & 90 & 11 \\
\hline 23 & 28 & Farm Worker & 1 & L5-S1 & + & 75 & 12 \\
\hline 24 & 21 & Driver & 1 & L5-S1 & + & 70 & 11 \\
\hline 25 & 24 & Carrier & 2 & L4-L5 & + & 55 & 9 \\
\hline 26 & 23 & Construction Worker & 2 & L5-S1 & + & 80 & 11 \\
\hline 27 & 21 & Construction Worker & 3 & L5-S1 & + & 90 & 8 \\
\hline 28 & 22 & Farm Worker & 1 & L5-S1 & + & 100 & 12 \\
\hline 29 & 26 & Construction Worker & 1 & L5-S1 & + & 60 & 11 \\
\hline 30 & 20 & Carrier & 1 & L5-S1 & + & 110 & 12 \\
\hline 31 & 21 & Butcher & 2 & L4-L5 & + & 90 & 10 \\
\hline 32 & 23 & Construction Worker & 1 & L5-S1 & + & 90 & 15 \\
\hline 33 & 29 & Carrier & 2 & L5-S1 & + & 80 & 12 \\
\hline 34 & 22 & Insurer & 2 & L4-L5 & + & 60 & 10 \\
\hline 35 & 25 & Construction Worker & 2 & L5-S1 & + & 75 & 13 \\
\hline 36 & 22 & Carrier & 2 & L5-S1 & + & 90 & 12 \\
\hline 37 & 27 & Carrier & 1 & L5-S1 & + & 60 & 9 \\
\hline 38 & 22 & Farm Worker & 2 & L5-S1 & + & 55 & 12 \\
\hline 39 & 23 & Construction Worker & 2 & L4-L5 & + & 90 & 14 \\
\hline 40 & 24 & Artisan & 1 & L5-S1 & + & 45 & 12 \\
\hline 41 & 24 & Farm Worker & 1 & L5-S1 & + & 75 & 14 \\
\hline 42 & 22 & Carrier & 1 & L5-S1 & + & 60 & 15 \\
\hline
\end{tabular}


Table 2: Oswestry Disability Index(ODI) and Visual Analog Scales(VAS) values of the patients before and after operation.

\begin{tabular}{ccc}
\hline & Preop & Postop \\
\hline ODI & 76.68 & 26.65 \\
VAS & 5.98 & 2.49 \\
\hline
\end{tabular}

The changes and defects occur in pars interarticularis in lumbar vertebrae play role in the etiology of isthmic spondylolisthesis [4-6]. Isthmic spondylolisthesis is seen $6 \%$ of 12 25 age population and usally develops in L5S1 level $[6,9]$. The most common complaints are lumbar pain and decreased lumbar range of motion in young adults [6]. Lumbar pain is thought to be caused by increase in lumbar lordosis due to chronic spasm in paravertebral muscles [8]. Disc pathologies and radiculopathy caused by narrowed foramen may be seen in young patients with severe spondylolisthesis [6]. Saraste et al. reported neurological findings are seen $2 \%$ of young adults with IS [8]. Patients in our study were classified as grade 1 IS and had the complaints of lumbar pain, decreased lumbar range of motion and worsening in symptoms with prolonged standing. None of our patients had lower extremity pain or neurological deficit.

Isthmic spondylolisthesis is classified under 3 different subtypes. Subtype A: Stress fracture occurs in pars interarticularis. Repetitive mechanical strain due to heavy work or sportive activity may cause stress fractures in pars interarticularis. In case these stress fractures are bilateral, the affected vertebra may slide forward over the lower vertebra. Subtype B: There is elongation in pars interarticularis. Microfractures heal with new bone formation. This causes elongation in pars interarticularis and vertebral body slides relatively forward. Usually develops in adolescence period and is the most common type in adolescents. Subtype C: Acute fracture in pars interarticularis. Subtype $C$ is the least common subtype $[9,10]$. Patients in our study were young and working in heavy duty occupations. We think that pars interarticularis stress fractures (subtype A) play role in the developement of pathology in our patients.

Conservative treatment should be considered in patients without neurological findings and having symptoms for a short period of time. In patients with neurological deficit or in case the medical treatment is failed to relieve symptoms, surgical intervention should be considered $[3,9]$.
Halting the progress of deformity by stabilisation of the unstable vertebrae is the main goal of surgical treatment.

The gold standard of IS treatment is fixation of unstable area and decompression of neural structures. The main goal is to achieve vertebral fusion. It is important to gain high spinal function in young and active patients after spinal instrumentation surgery. Surgical treatment of idiopathic spondylolisthesis includes posterolateral fusion, decompression, unilateral fusion, and addition of anterior support. There is a consensus in the literature about the addition of surgery to decompression. There is a decline in neurological and radical symptoms with decompression [11].

Molinari et al. reported that symptomatic patients with low grade spondylolisthesis may live a functional and painless life after spinal instrumentation [1]. Meyerding reported his results in 36 patients with spondylolisthesis after posterior fusion of lamina and spinous process with autograft. In his study clinical enhancement was seen in $88 \%$ of the patients [12]. Quantitative data in our study demonstrated that patients with low grade spondylolisthesis are having a more functional life with lower levels of pain following surgical treatment. Schulte et al. stated in their literature review that posterolateral fusion without instrumentation in young patients, is used for IS treatment in many countries and has better result than conservative treatment in 2-year follow-up [7]. Atabey et al. applied insitu posterolateral transpedicular fusion to 34 patients with lumbar spondylolisthesis over age 70. The authors mentioned significant clinical improvement in their assessment with ODI and VAS scores [11]. We didn't make decompression in our patients because they were young in age and had no radicular pain. Postoperative ODI and VAS scores in our patients were significantly better relative to preoperative scores after posterolateral in stu fusion and transpedicular fixation.

Implants used for fusion in the literature are pedicle screws and special cages used for interbody fusion. With the use of these 
implants, the physiologic lomber lordosis can be preserved and indirect decompression occurs along with the opening in the neural foramen. Sigmondson et al. have reported that with the addition of fusion to decompression surgery, there is more improvement in pain reduction, functional scores, and quality of life [13]. We did not decompress because there were no radiculopathy in our cases. We performed posterolateral fusion surgery for instability pain. Ye et al. have reported the rate of union in fusions using implants was significantly higher than unused ones, but there was no significant difference in pain and patient satisfaction [14].

In order to obtain fusion, posterolateral fusion can be used alone or posterior or anterior approach can be added to interbody fusion techniques to provide anterior column support and fusion. Interbody fusion techniques include; Anterior interbody fusion (ALIF), transforaminal interbody fusion (TLIF), and posterolateral interbody fusion (PLIF). Anterior column support and fusion rates are increased with the addition of the interbody fusion to surgery. The discogenic pain is reduced due to the cleaning of the disc material.

Although there is a significant increase in fusion ratios with interbody fusion techniques, there is no significant difference between these techniques in terms of fusion [15]. While ALIF from interbody fusion techniques is effective in improving the sagittal plan and providing $360^{\circ}$ fusion, the high morbidity rate brought by the anterior surgeon is seen as a disadvantage [15]. TLIF, which allows for interbody fusion with the foraminal approach, has similar results with less complication rate, while have been reported to perform PLIF application which is a posterior interbody fusion techniques in the canal and necessity of wide laminectomy as a disadvantage [16].

It is reported that transforaminal lumbar interbody fusion (TLIF) is the ideal test for ipsilateral decompression and this technique allows for ipsilateral decompression, anterior fusion, and posterior stabilization [17]. SorianoSánchez et al. reported that all patients were stabilized by minimally invasive transforaminal lumbar interbody fusion (MI-TLIF) in 33 patients unilaterally and in 34 patients by bilateral transpedicular fixation as a surgical treatment in their study of 67 patients with lumbar spondylolisthesis. They compared the two groups using VAS and ODI scales. They reported that there was no clinical difference between the two groups in the 1-year follow- up results [17]. Kabins et al. reported TLIF + spinal instrumentation results with unilateral (16 patients) and bilateral (20 patients) approach were satisfactory in 36 patients with isolated Lumbar 4-5 isthmic spondylolisthesis; but there was no clinical difference between the 2 surgical methods [18]. Xue et al, reported that there were no clinically and radiologically significant differences between unilateral and bilateral interventions in TLIF + spinal instrumentation in 80 spondylolisthesis cases, there is less blood, loss duration of hospital stay and decreased infection rate in unilateral intervention cases. [19] In our study, we followed postoperative follow-up of 42 patient with low grade isthmic spondylolisthesis with ODI and Oswestry scales. The results were statistically significant in terms of clinical improvement. It was a limiting factor that our study consisted of young male patients. In cases where we performed transpedicular fixation with the bilateral approach without TLIF, we obtained clinically satisfactory results with low cost.

Reduction of the vertebral stepping is still a controversial issue [7,20]. Although some authors stated that the reduction is beneficial for lumbosacral region functions [4], many others underlined the importance of postoperative complications, lower fusion rates and recommended in stu fusion [2,5,21]. Malposition of screws used in fusion surgery may cause neurological deficits and reduction may increase this risk [5]. Ziad et al. [3] were unable to find any difference in their cases in which they made fusion with or without reduction. Mikko et al. [21] reported better results without reduction in patients with low grade spondylolisthesis. Some authors in the literature recommend to correct sagittal plane deformities and state that widening in foramen due to reduction will provide adequate decompression of the neural structures $[4,6,8]$. The segment that reduction and fusion applied has better tolerance to mechanical strain and shear forces. Thus the risk of adjacent segment disease is decreased [3]. We did not apply reduction in our cases because our patients were grade 1 spondylolisthesis and they did not have foraminal narrowing.

Posterolateral in situ fusion and short segment spinal instrumentation in young IS patients results with good clinical outcome. Prospective and multicenter studies with 10-20 years follow-up are needed for further data.

Conflict of interest:The authors declared no conflict of interest. 


\section{References}

1. Molinari RW, Sloboda JF, Arrington EC. Low-grade isthmic spondylolisthesis treated with instrumented posterior lumbar interbody fusion in U.S. servicemen. J Spinal Disord Tech 2005;18:24-29.

2. Poussa M, Schlenzka D, Seitsalo S. Surgical treatment of severe isthmic spondylolisthesis in adolescents. Reduction or fusion in situ. Spine 1993;18:894-901.

3. Audat ZM, Darwish FT, Al Barbarawi MM et al. Surgical management of low grade isthmic spondylolisthesis; a randomized controlled study of the surgical fixation with and without reduction. Scoliosis 2011;6:14.

4. Shinya O, Takenori O, Ryoji Y, Takamitsu H, Takafumi M, Motoki I. Posterior lumbar interbody fusion with total facetectomy for low-dysplastic isthmic spondylolisthesis: effects of slip reduction on surgical outcomes J Neurosurg Spine 2014;21:171-178.

5. Sijbrandij S. A new technique for the reduction and stabilisation of severe spondylolisthesis. A report of two cases. J Bone Joint Surg Br 1981;63:266-271.

6. Thomas R. Jones, Raj D. Rao. Adult Isthmic Spondylolisthesis J Am Acad Orthop Surg 2009;17:609-617.

7. Schulte TL, Ringel $F$, Quante $M$, Eicker SO, Muche-Borowski C, Kothe R. Surgery for adult spondylolisthesis: a systematic review of the evidence. Eur Spine J. 2016;25:2359-2367

8. Saraste H. Long-term clinical and radiological followup of spondylolysis and spondylolisthesis. J Pediatr Orthop 1987;7:631-638.

9. Ganju A. Isthmic spondylolisthesis. Neurosurg Focus 2002;13:1-6.

10. Reames DL, Shaffrey CL. Pediatric spondylolithesis, Youmans Pediatric Neurological Surgey. Ed: Winn HR 6th Ed.2011:2935-2946

11. Atabey C, Gocmen S, Simsek H, et al. Surgical results of degenerative spondylolisthesis patients over 70 years old: a single-center experience and clinical outcomes. Turk Neurosurg 2012;22:534-539.

12. Meyerding HW. Spondylolisthesis: Surgical treatment and results. J Bone Joint Surg Am 1943;25:65.
13. Sigmundsson FG, Jönsson B, Strömqvist B. Outcome of decompression with and without fusion in spinal stenosis with degenerative spondylolisthesis in relation to preoperative pain pattern: a register study of 1,624 patients. Spine J 2015;15:638-646.

14. Ye YP, Xu H, Chen D. Comparison between posterior lumbar interbody fusion and posterolateral fusion with transpedicular screw fixation for isthmic spondylolithesis: a meta-analysis. Arch Orthop Trauma Surg. 2013;133:1649-1655.

15. Wang SJ, Han YC, Liu XM et al. Fusion techniques for adult isthmic spondylolisthesis: a systematic review. Arch Orthop Trauma Surg 2014;134:777-784.

16. Hackenberg L, Halm H, Bullmann V, Vieth V, Schneider M, Liljenqvist U. Transforaminal lumbar interbody fusion: a safe technique with satisfactory three to five year results. Eur Spine J 2005;14:551-558.

17. Soriano-Sánchez J, Quillo-Olvera J, Soriano-Solis S, et al. A prospective clinical study comparing MI-TLIF with unilateral versus bilateral transpedicular fixation in low grade lumbar spondylolisthesis Spine Surg 2017;3:16-22.

18. Kabins MB, Weinstein JN, Spratt KF, et al. Isolated L4L5 fusions using the variable screw placement system: unilateral versus bilateral. J Spinal Disord 1992;5:3949.

19. Xue H, Tu Y, Cai M. Comparison of unilateral versus bilateral instrumented transforaminal lumbar interbody fusion in degenerative lumbar diseases. Spine J 2012;12:209-215.

20. Lian XF, Hou TS, Xu JG, et al. Single segment of posterior lumbar interbody fusion for adult isthmic spondylolisthesis: reduction or fusion in situ. Eur Spine J 2014;23:172-179.

21. Mikko P, Ville R, Tommi L, et al. Treatment of Severe spondylolisthesis in adolescence with reduction or fusion in situ: long-term clinical, radiologic, and functional outcome spine 2009;31:583-590. 